\title{
GENETIC SUSCEPTIBILITY OF CYTOTOXIC T LYMPHOCYTE-ASSOCIATED ANTIGEN 4 GENE POLYMORPHISM IN THE ONSET OF ARTHRITIS
}

Running Tilte: Cytotoxic T Lymphocyte-Associated Antigen 4 Gene Polymorphism: An Important Predictor

\author{
Maryam Mukhtar ${ }^{1,2, *}$, Nadeem Sheikh ${ }^{1, *}$, Saira Kainat Suqaina1, Tayyaba Saleem ${ }^{1}$, Rabia \\ Mehmood $^{1}$, Muhammad Babar Khawar ${ }^{1,3}$ \\ ${ }^{1}$ Cell and Molecular Biology Lab, Department of Zoology, University of the Punjab, \\ Lahore, Pakistan. \\ ${ }^{1}$ Cell and Molecular Biology Lab, Department of Zoology, University of the Punjab, Lahore, \\ Pakistan \\ ${ }^{2}$ Rhumatology Domain, Center of Molecular Medicine, Karolinska Institute, Department of \\ Medicine, Stockholm, Sweden. \\ ${ }^{3}$ State Key Laboratory of Stem Cell and Reproductive Biology, Institute of Zoology, Chinese \\ Academy of Sciences, Beijing, China.
}

\section{*Corresponding Author}

E-mail address: s_nadeem77@yahoo.com

Mailing address: Cell and Molecular Biology Lab, Department of Zoology, University of the Punjab, Quaid-i-Azam Campus, Lahore, 54590

Telephone

No: +923224222036

\section{KEYWORDS}

Rheumatoid arthritis; Osteoarthritis, Haplotype, PCR-RFLP, CTLA-4 gene, Sequencing.

\section{SUMMARY STATEMENT}

The study summarized that CTLA-4 gene polymorphism plays a key role in the arthritis onset in Pakistani population. 
medRxiv preprint doi: https://doi.org/10.1101/2021.04.27.21255970; this version posted April 29, 2021. The copyright holder for this preprint (which was not certified by peer review) is the author/funder, who has granted medRxiv a license to display the preprint in perpetuity.

It is made available under a CC-BY-ND 4.0 International license .

\begin{abstract}
Cytotoxic T lymphocyte-associated antigen 4 (CTLA-4) gene plays a vital role in the activation of T-cells as a down regulator. CTLA-4 gene polymorphisms have implicated a potential risk factor for autoimmune disorders like arthritis. Therefore the current study was designed to determine the association of CTLA-4 gene polymorphism in the onset of rheumatoid and osteoarthritis in Pakistani individuals. Genotyping was performed on 300 RA, 316 OA, and 412 control subjects by direct sequencing method as well as polymerase chain reaction-restriction fragment length polymorphism (PCR-RFLP) technique. It was observed that allelic and genotypic frequency of rs5742909, rs231775, rs4553808, rs733618, and rs3087243 were significantly varied among patients and controls and considered as a significant risk factor in the onset of RA as well as OA. However, no mutation was identified on the rs 11571317 polymorphic site. Haplotype CAGTCA and CAG TCG act as a protectant against disease onset whereas CAACCG was significant in disease onset. Mutation on rs231775 polymorphic site lead to the change of threonine into alanine It was concluded that CTLA-4 gene polymorphism is a significant risk factor in the onset of RA as well as OA. Large scale survey is required for the screening of the genetic markers for pre-diagnosis of the disease.
\end{abstract}


medRxiv preprint doi: https://doi.org/10.1101/2021.04.27.21255970; this version posted April 29, 2021. The copyright holder for this preprint (which was not certified by peer review) is the author/funder, who has granted medRxiv a license to display the preprint in perpetuity. It is made available under a CC-BY-ND 4.0 International license .

\section{Introduction}

An inflammatory disorder named arthritis affects multiple body joints with varying factors like infections, trauma, autoimmune disorders, aging and idiopathic causes (1). It has multiple types whereas two were of major i-e., Rheumatoid arthritis (RA) and Osteoarthritis (OA). A systematic disease RA is characterized by debilitating, destructive and chronic arthritis (2). However OA is changes in articular cartilage, related changes in joint margins, underlying bones (3).

Arthritis is polygenic disorder and caused by interaction of mutations on multiple genes like PADI-4, PTPN22 and CTLA-4 (4;5). Cytolytic T lymphocyte-associated antigen $4(C T L A-4)$ negatively regulate responses of immuno $\mathrm{T}$ cells and vital checkpoint in altering antitumor responses and autoimmunity. Polymorphisms on CTLA-4 genes in humans altered CTLA-4 that ultimately lead to the immune dysregulation syndromes onset (6).

CTLA-4 gene was located on chromosome 2q33 comprised of a leader sequence and 3 exons as well as exist as monocopy per haploid genome $(7 ; 8)$. Three polymorphism sites were reported on CTLA-4 locus. Out of which first polymorphism was the dinucleotide i-e., (AT)n repeat at $642 \mathrm{bp}$ of exon 3 . The second polymorphic site was transition of G to A at 49 (G49A) position of exon 1(9). While the third was first reported by (7), and of $\mathrm{C}$ to $\mathrm{T}$ transition of promotor sequence at $-318(\mathrm{C}-318 \mathrm{~T})$ position.

Pakistan because of intracaste marriages is at higher risk of genetic disorders including arthritis which is the leading cause of disability. With increasing age the risk of disease development also increasing. However the basic genetic factors associated with arthritis is still 
medRxiv preprint doi: https://doi.org/10.1101/2021.04.27.21255970; this version posted April 29, 2021. The copyright holder for this preprint (which was not certified by peer review) is the author/funder, who has granted medRxiv a license to display the preprint in perpetuity. It is made available under a CC-BY-ND 4.0 International license .

unknown. There for the aim and objective of present study is to determined the susceptible association of CTLA-4 gene aith the onset of RA as well OA on studied population.

\section{Result}

As a result of genotyping it was observed that polymorphism exist on all targeted polymorphic sites on CTLA-4 gene except rs11571317. On rs5742909 site, T allele was more prevalent among patients as compared to $\mathrm{C}$ allele. Similarly $\mathrm{G}$ allele was more prevalent on rs231775 and rs4553808 among patients instead of allele A. C allele was replaced by T allele on rs733618 and on rs3087243 polymorphic site allele $\mathrm{G}$ was more common among patients as compared to controls. All SNP's followed HWE ( $\mathrm{p}>1.00)$. The allelic and genetic analysis was performed and was presented in table 2 and 3. No mutation was observed on rs 11571317 polymorphic site. The allelic frequency of mutant allele on rs231775, rs733618 and rs3087243 were significantly varied among RA patients and control. However in OA patient's rs5742909, rs231775, rs4553808 and rs3087243 were significantly varied in comparison to controls (p < 0.01). At genetic level, it was observed that all SNP's except rs5742909 were significantly associated with the onset of RA ( $p<0.01)$ where as in OA rs733618 was not significantly associated with onset of disease $(\mathrm{p}<0.01)$.

Linkage disequilibrium analysis was presented in Figure $1(\mathrm{a}, \mathrm{b})$ in RA patients and Figure $2(a, b)$ in OA patients. In comparison of controls, in RA rs5742909 with rs231775 were higher risk factor $\left(D^{\prime}=0.975 ;\right.$ r2=0.787) followed by rs11571317 along with rs5742909 and rs231775 ( $\left.\mathrm{D}^{\prime}=0.840, \mathrm{r} 2=0.465\right)$ and $\left(\mathrm{D}^{\prime}=0.831, \mathrm{r} 2=0.529\right)$ respectively. Whereas variants on rs231775, rs4553808 and 733618 in combination were increased chances on RA development. On other hand, in OA subjects and controls if all SNP's will forward to next generation they all 
medRxiv preprint doi: https://doi.org/10.1101/2021.04.27.21255970; this version posted April 29, 2021. The copyright holder for this preprint (which was not certified by peer review) is the author/funder, who has granted medRxiv a license to display the preprint in perpetuity. It is made available under a CC-BY-ND 4.0 International license .

in combination increased chances of disease onset $\left(D^{\prime}=1.000, r 2=0.401\right)$. if $r$ s 733618 , rs1 1571317 and rs3087243 were significant risk factor in combination $\left(D^{\prime}=0.914, r 2=0.512\right)$.

It was observed that in RA and OA subjects, the frequency of haplotypes CAGTCA and CAGTCG was higher in controls as compared to patients therefore they were protective against disease onset. The haplotypes significant in disease onset were summarized in Table 4.

As a result of protein alignment on MEGA6 software, it was observed that polymorphism on rs231775 lead to the change of threonine into alanine.

\section{Discussion}

During various phases of $\mathrm{T}$ cells response, CTLA-4 performed different independent effects such as apoptosis induction in activated $\mathrm{T}$ cells as well as to suppress proliferation of $\mathrm{T}$ cells or CTLA-4 may directly regulate B cells responses (10). The current study was designed with an aim to investigate the susceptibility of CTLA-4 gene functional polymorphisms with the onset of arthritis.

Multiple SNP's were identified on studied gene out of which some variants were reported to be associated with the onset of autoimmune disorders like rheumatoid arthritis and Sjogren's Syndrome (11-13). Current study demonstrated that except rs11571302, all other studied SNP's including rs5742909, rs231775, rs4553808, rs733618 and rs3087243 polymorphic sites were significantly associated with the onset of RA as well as OA. Similarly rs5742909 and rs231775 were reported as significant susceptible genetic markers in onset of RA (14-16). Similarly rs3087243 was reported as significant risk factor in the onset of RA in Mexican, Chinese and North American populations (17-19). Contrary to this polymorphism on rs5742909 was reported 
medRxiv preprint doi: https://doi.org/10.1101/2021.04.27.21255970; this version posted April 29, 2021. The copyright holder for this preprint (which was not certified by peer review) is the author/funder, who has granted medRxiv a license to display the preprint in perpetuity. It is made available under a CC-BY-ND 4.0 International license .

as non significant factor in the onset of RA in Mexican, Spanish and Korean populations (19-21). Rs231775 was also reported as non-significant factor in the onset of RA in british population $(5 ; 22 ; 23)$.

Currently studied polymorphisms were already reported as functional and involved in altering immune response. Mutant allele T on rs5742909 polymorphic site was reported to be involved in elevating activity of promotor which ultimately increased expression of gene and protein of $C T L A-4$ mRNA and membrane CTLA-4 respectively. It also suppressed immune response by negatively regulate $\mathrm{T}$ cells $(24 ; 25)$.

Whereas polymorphism on rs231775 site was involved in altering activation of $\mathrm{T}$ cells and CTLA-4 inhibitory function. Allele $\mathrm{G}$ on above mentioned polymorphic site lowered protein expression which decreased control on $\mathrm{T}$ cells activation and proliferation lead to the onset of autoimmune disorders including $\mathrm{RA}$ by altering $\mathrm{T}$ cells regulation $(14 ; 24 ; 26-28)$. It was postulated that mutation on rs231775 may also influenced surface trafficking and endocytosis, glycosylation of CTLA-4 and intracellular portioning which ultimately affected its inhibitory action (29).

Polymorphism on promotor region (rs733618 and rs4553808) of reported to be involved in alternative abnormal slicing which affects gene expression and hence contribute in RA and OA pathogenesis (30)

In pipeline of this, the mutant $\mathrm{G}$ allele on rs3087243 polymorphic site altered level of cytoplasmic and membrane CTLA-4 along with sCTLA-4 mRNA and sCTLA-4 levels (31;32). 
medRxiv preprint doi: https://doi.org/10.1101/2021.04.27.21255970; this version posted April 29, 2021. The copyright holder for this preprint

(which was not certified by peer review) is the author/funder, who has granted medRxiv a license to display the preprint in perpetuity.

It is made available under a CC-BY-ND 4.0 International license .

Current study demonstrated haplotype CAGTCA and CAGTCG were protective against disease onset in Pakistani population where as rest haplotypes were significant risk factors in the onset of disease. Up to best of my knowledge current study is the first ever study reporting the association of functional polymorphic sites of $C T L A-4$ gene with RA as well as OA in Pakistani population.

In conclusion it was found that $C T L A-4$ is a significant risk factor in the onset of not only RA as well OA. However a large scale screening must be needed so that the above mentioned genetic markers can be used for the pre diagnosis of the disease.

\section{Materials and Methods}

\section{Sampling}

For meeting the above mentioned objective a case control study was designed and ethically approved by the Punjab University Advanced Studies and Research Board, Lahore, Pakistan. The study was recruited from the rheumatology and orthopedic center of Public and Semi Government Hospitals of Punjab, Pakistan. Already diagnosed individuals with disease were selected after taking written consent. The study was comprised of 300 RA, 316 OA and 412 controls subjects. All RA subjects were with positive Rf factor where as OA were with negative Rf Factor. All control subjects' age and sex matched to the cases and were healthy as well as with negative family history of arthritis.

\section{Genotyping}

DNA was isolated by manually from each blood sample and was stored at $-80^{\circ} \mathrm{C}$. Genotyping was performed for selected polymorphic sites by sanger's sequencing method (S. 
medRxiv preprint doi: https://doi.org/10.1101/2021.04.27.21255970; this version posted April 29, 2021. The copyright holder for this preprint

(which was not certified by peer review) is the author/funder, who has granted medRxiv a license to display the preprint in perpetuity.

It is made available under a CC-BY-ND 4.0 International license .

Figure 1) as well as PCR-RFLP technique (S. Figure 2). The primer with respect to the targeted polymorphic sites along with their respective endonucleases enzymes (Thermo Scientific) and conditions was summarized in table 1.

\section{Statistical Analysis}

For genetic analysis whole data was passed through Hardy-Weinberg Equilibrium (p> 0.05). The Fisher's P test was used for allelic and genotypic frequencies. Linkage disequilibrium level and haplotype were calculated to study the studied SNP's association with arthritis by SHEsis (http://analysis.bio-x.cn/SHEsisMain.htm). Alterations in amino acid sequences were determined by Mega 6 software.

\section{Acknowledgement}

Authors are thankful to Higher Education Commission and worthy Vice Chancellor, University of the Punjab, and Lahore for providing funding for accomplishment of research.

\section{Competing Interest}

There is no conflict of interest.

\section{Funding}

The current study is funded by Higher Education Commission Lahore.

\section{Reference List}

(1) Arend WP. The pathophysiology and treatment of rheumatoid arthritis. Arthritis \& Rheumatism: Official Journal of the American College of Rheumatology 1997;40(4):595-7. 
medRxiv preprint doi: https://doi.org/10.1101/2021.04.27.21255970; this version posted April 29, 2021. The copyright holder for this preprint (which was not certified by peer review) is the author/funder, who has granted medRxiv a license to display the preprint in perpetuity. It is made available under a CC-BY-ND 4.0 International license .

(2) Gabriel SE, Crowson CS, O'Fallon M. The epidemiology of rheumatoid arthritis in Rochester, Minnesota, 1955-1985. Arthritis \& Rheumatism: Official Journal of the American College of Rheumatology 1999;42(3):415-20.

(3) Kafil N, Aamir K, Murad S, Ara J, Anjum S. A placebo controlled clinical trial on Nimesulide in Osteoarthritis. J Surg Pakistan 2003;8:5-8.

(4) Begovich AB, Carlton VE, Honigberg LA, Schrodi SJ, Chokkalingam AP, Alexander HC, et al. A missense single-nucleotide polymorphism in a gene encoding a protein tyrosine phosphatase (PTPN22) is associated with rheumatoid arthritis. The American Journal of Human Genetics 2004;75(2):330-7.

(5) Vaidya B, Pearce SHS, Charlton S, Marshall N, Rowan AD, Griffiths ID, et al. An association between the CTLA4 exon 1 polymorphism and early rheumatoid arthritis with autoimmune endocrinopathies. Rheumatology 2002;41(2):180-3.

(6) Khailaie S, Rowshanravan B, Robert PA, Waters E, Halliday N, Herrera JDB, et al. Characterization of CTLA4 trafficking and implications for its function. Biophysical journal 2018;115(7):1330-43.

(7) Dariavach P, Matti MG, Golstein P, Lefranc MP. Human Ig superfamily CTLA-4 gene: chromosomal localization and identity of protein sequence between murine and human CTLA-4 cytoplasmic domains. European journal of immunology 1988;18(12):1901-5.

(8) Harper K, Balzano CHRI, Rouvier ERIC, Matt+-i MG, Luciani MF, Golstein P. CTLA-4 and CD28 activated lymphocyte molecules are closely related in both mouse and human as to sequence, message expression, gene structure, and chromosomal location. The Journal of Immunology 1991;147(3):1037-44.

(9) Nistic L, Buzzetti R, Pritchard LE, Van der Auwera B, Giovannini C, Bosi E, et al. The CTLA-4 gene region of chromosome 2 q33 is linked to, and associated with, type 1 diabetes. Human molecular genetics 1996;5(7):1075-80.

(10) Brunner-Weinzierl MC. Multiple functions for CD28 and cytotoxic T lymphocyte antigen-4 during different phases of T cell responses: implications for arthritis and autoimmune diseases. 2004.

(11) Rodrguez MR, Nunez-Roldan A, Aguilar F, Valenzuela A, Garca A, Gonzalez-Escribano MF. Association of the CTLA4 3 untranslated region polymorphism with the susceptibility to rheumatoid arthritis. Human immunology 2002;63(1):76-81.

(12) Ueda H, Howson JM, Esposito L, Heward J, Chamberlain G, Rainbow DB, et al. Association of the T-cell regulatory gene CTLA4 with susceptibility to autoimmune disease. Nature 2003;423(6939):506.

(13) Downie Doyle S, Bayat N, Rischmueller M, Lester S. Influence of CTLA4 haplotypes on susceptibility and some extraglandular manifestations in primary Sjgren's syndrome. Arthritis \& Rheumatism: Official Journal of the American College of Rheumatology 2006;54(8):2434-40. 
medRxiv preprint doi: https://doi.org/10.1101/2021.04.27.21255970; this version posted April 29, 2021. The copyright holder for this preprint

(which was not certified by peer review) is the author/funder, who has granted medRxiv a license to display the preprint in perpetuity.

It is made available under a CC-BY-ND 4.0 International license .

(14) Muoz-Valle JF, Valle $Y$, Padilla-Guti+־rrez JR, Parra-Rojas I, Rangel-Villalobos $H$, del Mercado $\mathrm{MnV}$, et al. The+ 49A> G CTLA-4 polymorphism is associated with rheumatoid arthritis in Mexican population. Clinica Chimica Acta 2010;411(9-10):725-8.

(15) Yanagawa TATS, Gomi KIYO, Nakao EI, Inada SHIN. CTLA-4 gene polymorphism in Japanese patients with rheumatoid arthritis. The Journal of rheumatology 2000;27(12):2740-2.

(16) Liu CP, Jiang JA, Wang T, Liu XM, Gao L, Zhu RR, et al. CTLA-4 and CD86 genetic variants and haplotypes in patients with rheumatoid arthritis in southeastern China. Genet Mol Res 2013;12(2):1373-82.

(17) Plenge RM, Padyukov L, Remmers EF, Purcell S, Lee AT, Karlson EW, et al. Replication of putative candidate-gene associations with rheumatoid arthritis in $>4,000$ samples from North America and Sweden: association of susceptibility with PTPN22, CTLA4, and PADI4. The American Journal of Human Genetics 2005;77(6):1044-60.

(18) Lei C, Dongqing Z, Yeqing S, Oaks MK, Lishan C, Jianzhong J, et al. Association of the CTLA-4 gene with rheumatoid arthritis in Chinese Han population. European journal of human genetics 2005;13(7):823.

(19) Torres-Carrillo N, Ontiveros-Mercado H, Torres-Carrillo NM, Parra-Rojas I, Rangel-Villalobos H, Ramrez-Due+as MG, et al. The $+319 \mathrm{C} /+49 \mathrm{G} / \mathrm{CT} 60 \mathrm{G}$ haplotype of CTLA-4 gene confers susceptibility to rheumatoid arthritis in Mexican population. Cell biochemistry and biophysics 2013;67(3):1217-28.

(20) Lee YH, Choi SJ, Ji JD, Song GG. No association of polymorphisms of the CTLA-4 exon 1 (+ 49) and promoter $(-318)$ genes with rheumatoid arthritis in the Korean population. Scandinavian journal of rheumatology 2002;31(5):266-70.

(21) Barton A, Jury F, Eyre S, Bowes J, Hinks A, Ward D, et al. Haplotype analysis in simplex families and novel analytic approaches in a case control cohort reveal no evidence of association of the CTLAГÇÉ4 gene with rheumatoid arthritis. Arthritis \& Rheumatism 2004;50(3):748-52.

(22) Barton A, Myerscough A, John S, Gonzalez-Gay M, Ollier W, Worthington J. A single nucleotide polymorphism in exon 1 of cytotoxic T-lymphocyte-associated-4 (CTLA-4) is not associated with rheumatoid arthritis. Rheumatology 2000;39(1):63-6.

(23) Milicic A, Brown MA, Wordsworth BP. Polymorphism in codon 17 of the CTLA-4 gene (+ 49 A/G) is not associated with susceptibility to rheumatoid arthritis in British Caucasians. Tissue antigens 2001;58(1):50-4.

(24) Ligers A, Teleshova N, Masterman T, Huang WX, Hillert J. CTLA-4 gene expression is influenced by promoter and exon 1 polymorphisms. Genes and immunity 2001;2(3):145.

(25) Wang XB, Zhao X, Giscombe R, Lefvert AK. A CTLA-4 gene polymorphism at position +318 in the promoter region affects the expression of protein. Genes and immunity 2002;3(4):233. 
medRxiv preprint doi: https://doi.org/10.1101/2021.04.27.21255970; this version posted April 29, 2021. The copyright holder for this preprint

(which was not certified by peer review) is the author/funder, who has granted medRxiv a license to display the preprint in perpetuity.

It is made available under a CC-BY-ND 4.0 International license .

(26) Ahmed S, Ihara K, Kanemitsu S, Nakashima H, Otsuka T, Tsuzaka K, et al. Association of CTLA-4 but not CD28 gene polymorphisms with systemic lupus erythematosus in the Japanese population. Rheumatology 2001;40(6):662-7.

(27) Han S, Li Y, Mao Y, Xie Y. Meta-analysis of the association of CTLA-4 exon-1+ 49A/G polymorphism with rheumatoid arthritis. Human genetics $2005 ; 118(1): 123$.

(28) Kristiansen OP, Larsen ZM, Pociot F. CTLA-4 in autoimmune diseases a general susceptibility gene to autoimmunity? Genes and immunity 2000;1(3):170.

(29) Anjos S, Nguyen A, Ounissi-Benkalha H, Tessier MC, Polychronakos C. A common, autoimmunity predisposing signal peptide variant of the cytotoxic T-lymphocyte antigen-4 results in inefficient glycosylation of the susceptibility allele. Journal of Biological Chemistry 2002.

(30) Wang XB, Pirskanen R, Giscombe R, Lefvert AK. Two SNPs in the promoter region of the CTLA-4 gene affect binding of transcription factors and are associated with human myasthenia gravis. Journal of internal medicine 2008;263(1):61-9.

(31) Daroszewski J, Pawlak E, Karabon L, Frydecka I, Jonkisz A, Slowik M, et al. Soluble CTLA-4 receptor an immunological marker of Graves' disease and severity of ophthalmopathy is associated with CTLA-4 Jo31 and CT60 gene polymorphisms. European journal of endocrinology 2009;161(5):787-93.

(32) Karabon L, Kosmaczewska A, Bilinska M, Pawlak E, Ciszak L, Jedynak A, et al. The CTLA-4 gene polymorphisms are associated with CTLA-4 protein expression levels in multiple sclerosis patients and with susceptibility to disease. Immunology 2009;128(1pt2):e787-e796. 
medRxiv preprint doi: https://doi.org/10.1101/2021.04.27.21255970; this version posted April 29, 2021. The copyright holder for this preprint (which was not certified by peer review) is the author/funder, who has granted medRxiv a license to display the preprint in perpetuity.

It is made available under a CC-BY-ND 4.0 International license .

Figure 1. Location and map of Linkage Disequilibrium (LD) in SNPs at CTLA-4 gene in RA are presented. The SNPs numbers are indicated at the top of haploview. (a) $L D=D^{\prime}$ (b) $r^{2}=L D$ Coefficient.

Figure 2. Location and map of Linkage Disequilibrium (LD) in SNPs at CTLA-4 gene in OA are presented. The SNPs numbers are indicated at the top of haploview. (a) $L D=D^{\prime}$ (b) $r^{2}=L D$ Coefficient. 
medRxiv preprint doi: https://doi.org/10.1101/2021.04.27.21255970; this version posted April 29, 2021. The copyright holder for this preprint (which was not certified by peer review) is the author/funder, who has granted medRxiv a license to display the preprint in perpetuity.

It is made available under a CC-BY-ND 4.0 International license.

Table 1: PCR and RFLP enzymes conditions for selected SNP's on CTLA-4 gene.

\begin{tabular}{|c|c|c|c|c|c|}
\hline SNP No & F.P & R.P & $\begin{array}{l}\text { A.T } \\
\left({ }^{\circ} \mathrm{C}\right)\end{array}$ & $\begin{array}{l}\text { RFLP } \\
\text { Enzym } \\
\text { e }\end{array}$ & $\begin{array}{l}\text { Enzyme } \\
\text { O.T }\left({ }^{\circ} \mathrm{C}\right)\end{array}$ \\
\hline rs5742909 & $\begin{array}{l}\text { AAATGAATTGGACTGG } \\
\text { ATGGT }\end{array}$ & $\begin{array}{l}\text { TTACGAGAAAGGAAGCCG } \\
\text { TG }\end{array}$ & 56 & MseI & 65 \\
\hline rs231775 & $\begin{array}{l}\text { AGTCTCACTCACCTTTG } \\
\text { CAG }\end{array}$ & $\begin{array}{l}\text { GCTCTACCTCTTGAAGACC } \\
\mathrm{T}\end{array}$ & 59 & Eco9II & 37 \\
\hline rs4553808 & $\begin{array}{l}\text { CTAAGAGCATCCGCTT } \\
\text { GCACCT }\end{array}$ & $\begin{array}{l}\text { TTGGTGTGATGCACAGAA } \\
\text { GCCTTT }\end{array}$ & 64 & DraI & 37 \\
\hline rs733618 & $\begin{array}{l}\text { CTAAGAGCATCCGCTT } \\
\text { GCACCT }\end{array}$ & $\begin{array}{l}\text { TTGGTGTGATGCACAGAA } \\
\text { GGGTTTT }\end{array}$ & 64 & ApekI & 37 \\
\hline rs11571317 & $\begin{array}{l}\text { ATCATTGGTCCTGTCTA } \\
\text { CAGC }\end{array}$ & $\begin{array}{l}\text { CTTCTAATGGTCCCTTGAC } \\
\text { AG }\end{array}$ & 56 & AciI & 37 \\
\hline rs3087243 & $\begin{array}{l}\text { ATAATGCTTCATGAGTC } \\
\text { AGCTT }\end{array}$ & $\begin{array}{l}\text { GAG } \\
\text { GTGAAGAACCTGTGTTAA } \\
\text { A }\end{array}$ & 57 & $\begin{array}{l}\text { HpyCH } \\
{ }_{4} \mathrm{IV}\end{array}$ & 65 \\
\hline
\end{tabular}


Table 2. Allelic test of genetic variants of CTLA-4 gene in RA, OA and controls.

\begin{tabular}{|c|c|c|c|c|c|}
\hline & & $\mathbf{R A}$ & & $\mathbf{O A}$ & \\
\hline SNP's & Alleles & $\begin{array}{l}\text { Frequency } \\
\text { (P/C) }\end{array}$ & p-value & $\begin{array}{l}\text { Frequency } \\
\text { (P/C) }\end{array}$ & p-value \\
\hline \multirow{2}{*}{ rs5742909 } & $\mathrm{C}$ & $0.302 / 1.000$ & \multirow{2}{*}{$<0.01$} & $0.419 / 0.164$ & \multirow{2}{*}{$0.016^{*}$} \\
\hline & $\mathrm{T}$ & $0.698 / 0.000$ & & $0.581 / 0.836$ & \\
\hline \multirow{2}{*}{ rs231775 } & $\mathrm{A}$ & $0.225 / 1.000$ & \multirow{2}{*}{$0.017 *$} & $0.217 / 1.000$ & \multirow{2}{*}{$0.015^{*}$} \\
\hline & $\mathrm{G}$ & $0.775 / 0.000$ & & $0.581 / 0.000$ & \\
\hline \multirow{3}{*}{ rs4553808 } & $\mathrm{A}$ & $0.737 / 0.000$ & \multirow{3}{*}{$<0.01$} & $0.828 / 0.038$ & \multirow{3}{*}{$0.016 *$} \\
\hline & & & & & \\
\hline & $\mathrm{G}$ & $0.263 / 1.000$ & & $0.172 / 0.962$ & \\
\hline \multirow{2}{*}{ rs733618 } & $\mathrm{C}$ & $0.920 / 0.000$ & \multirow{2}{*}{$0.015^{*}$} & $0.540 / 0.000$ & \multirow{2}{*}{$<0.01$} \\
\hline & $\mathrm{T}$ & $0.080 / 1.000$ & & $0.460 / 1.000$ & \\
\hline rs11571317 & $\mathrm{C}$ & $1.000 / 1.000$ & - & $1.000 / 1.000$ & - \\
\hline \multirow[t]{2}{*}{ rs3087243 } & $\mathrm{A}$ & $0.457 / 0.917$ & \multirow[t]{2}{*}{$0.015^{*}$} & $0.055 / 0.917$ & \multirow[t]{2}{*}{$0.016^{*}$} \\
\hline & $\mathrm{G}$ & $0.543 / 0.083$ & & $0.945 / 0.083$ & \\
\hline
\end{tabular}

* Represents significance at the 0.01 level. 
Table 3. Genetic test of genetic variants of CTLA-4 gene in RA, OA and controls.

\begin{tabular}{|c|c|c|c|c|c|}
\hline SNP's & Genotypes & $\begin{array}{l}\text { RA } \\
\text { Frequency } \\
\text { (P/C) }\end{array}$ & $\begin{array}{l}p- \\
\text { value }\end{array}$ & $\begin{array}{l}\text { OA } \\
\text { Frequency } \\
\text { (P/C) }\end{array}$ & p-value \\
\hline \multirow{3}{*}{ rs5742909 } & $\mathrm{CC}$ & $0.067 / 1.000$ & \multirow{3}{*}{$0.016^{*}$} & $0.089 / 1.000$ & \multirow{3}{*}{$<0.01$} \\
\hline & $\mathrm{CT}$ & $0.470 / 0.036$ & & $0.661 / 0.000$ & \\
\hline & TT & $0.463 / 0.964$ & & $0.250 / 0.00$ & \\
\hline \multirow{3}{*}{ rs231775 } & AA & $0.040 / 1.000$ & \multirow{3}{*}{$0.015^{*}$} & $0.038 / 1.000$ & \multirow{3}{*}{0.132} \\
\hline & $\mathrm{AG}$ & $0.370 / 0.000$ & & $0.358 / 0.000$ & \\
\hline & GG & $0.590 / 0.000$ & & $0.604 / 0.002$ & \\
\hline \multirow{3}{*}{ rs4553808 } & $\mathrm{CC}$ & $0.473 / 0.000$ & \multirow{3}{*}{$0.016^{*}$} & $0.828 / 0.000$ & \multirow{3}{*}{$0.001 *$} \\
\hline & $\mathrm{CT}$ & $0.527 / 0.000$ & & $0.010 / 0.000$ & \\
\hline & TT & $0.000 / 1.000$ & & $0.162 / 1.000$ & \\
\hline \multirow{3}{*}{ rs733618 } & $\mathrm{CC}$ & $0.840 / 0.000$ & \multirow{3}{*}{$<0.01$} & $0.079 / 0.000$ & \multirow{3}{*}{$0.015^{*}$} \\
\hline & $\mathrm{CT}$ & $0.160 / 0.000$ & & $0.921 / 0.000$ & \\
\hline & TT & $0.000 / 1.000$ & & $0.000 / 1.000$ & \\
\hline
\end{tabular}


medRxiv preprint doi: https://doi.org/10.1101/2021.04.27.21255970; this version posted April 29, 2021. The copyright holder for this preprint (which was not certified by peer review) is the author/funder, who has granted medRxiv a license to display the preprint in perpetuity.

It is made available under a CC-BY-ND 4.0 International license .

\begin{tabular}{|l|l|l|l|l|l|}
\hline rs11571317 & CC & $1.000 / 1.000$ & - & $1.000 / 1.000$ & \\
\hline \multirow{3}{*}{ rs3087243 } & AA & $0.097 / 0.835$ & & $0.089 / 0.935$ & \\
\cline { 2 - 3 } & AG & $0.720 / / 0.165$ & $0.015^{*}$ & $0.730 / 0.065$ & \multirow{2}{*}{$0.001^{*}$} \\
\cline { 2 - 3 } & & & & & \\
\cline { 2 - 3 } & GG & $0.183 / 0.000$ & & $0.183 / 0.000$ & \\
& & & & & \\
\hline
\end{tabular}

* Represents significance at the 0.05 level. 
Table 4. Haplotype Analysis of the CTLA-4 gene located on chromosome 2.

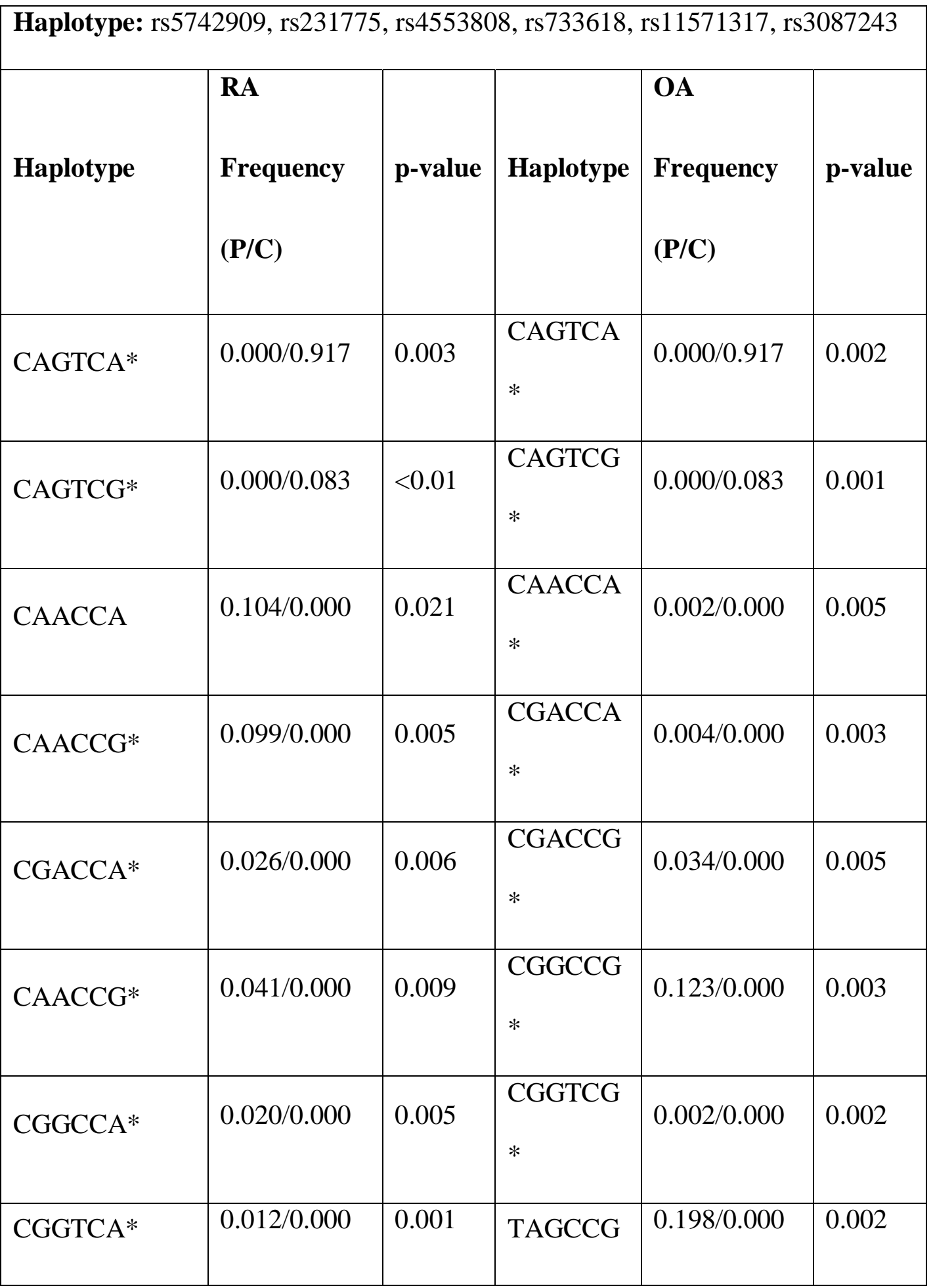


medRxiv preprint doi: https://doi.org/10.1101/2021.04.27.21255970; this version posted April 29, 2021. The copyright holder for this preprint (which was not certified by peer review) is the author/funder, who has granted medRxiv a license to display the preprint in perpetuity.

It is made available under a CC-BY-ND 4.0 International license .

\begin{tabular}{|c|c|c|c|c|c|}
\hline & & & $*$ & & \\
\hline TAACCG* & $0.023 / 0.000$ & 0.005 & $\begin{array}{l}\text { TGGCCG } \\
*\end{array}$ & $0.024 / 0.000$ & 0.006 \\
\hline TGACCA* & $0.063 / 0.000$ & 0.001 & TGGTCG & $0.359 / 0.000$ & 0.021 \\
\hline TGACCG* & $0.381 / 0.000$ & 0.002 & & & \\
\hline TGGCCA* & $0.163 / 0.000$ & 0.002 & & & \\
\hline TGGTCA* & $0.068 / 0.000$ & 0.001 & & & \\
\hline
\end{tabular}

*Represents a significant association of Haplotypes with Arthritis onset.

Represents a significant association of Haplotypes protective against Arthritis onset 


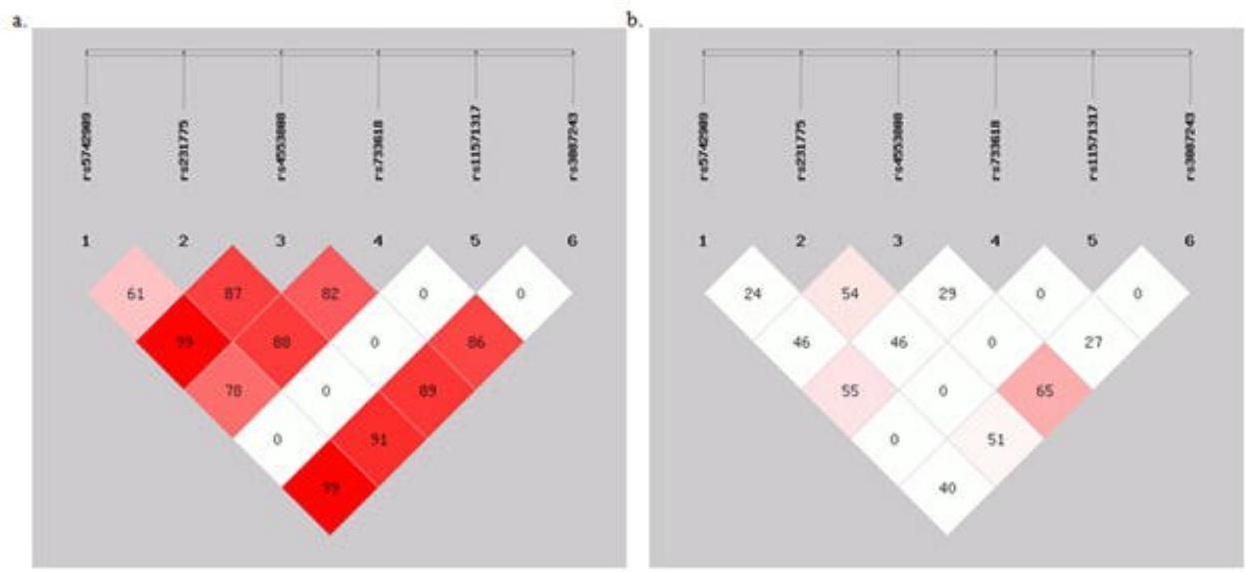

